\title{
ОСОБЛИВОСТІ ВПРОВАДЖЕННЯ ЕКОЛОГІЧНО ЧИСТИХ ТЕХНОЛОГІЙ В ЕНЕРГЕТИЦ УКРАЇНИ
}

\author{
В.А. Хілько ${ }^{1}$, науковий співробітник, В.Ю. Іванчук ${ }^{\mathbf{1}, 2}$, студент \\ ${ }^{1}$ Інститут відновлюваної енергетики НАН України, \\ 02094, вул. Гната Хоткевича, 20А, м. Київ, Україна. \\ ${ }^{2}$ Національний технічний університет України «Київський політехнічний інститут ім. Ігоря Сікорського», \\ 03056, пр-т. Перемоги, 37, м. Київ, Україна.
}

\begin{abstract}
Мета статті - визначення шляхів зменшення викидів парникових газів, які суттєво вливають на тепловий баланс землі. Доповідь 2019 року про розрив в рівнях викидів, яка підготовлена Програмою ООН з навколишнього середовища, свідчить, щзо заходи по поточній політиці скорочення шкідливих викидів, явно недостатні. В світі спостерігається постійний зростаючий інтерес до відновлюваних джерел енергї̈, викликаний екологічними міркуваннями: зміна клімату $і$ збільшення вмісту в атмосфері парникових газів. В Україні стрімким темпом розвивається використання відновлюваних джерел енергії, зокрема вітряної та сонячної енергії. Разом з тим при вводі нових потужностей об'єктів на базі ВДЕ існують проблеми мережевого та системного характеру. Тому збільшення потужностей ВДЕ потребує створення в Україні більш гнучкої енергосистеми, в тому числі вирішення питання з резервними $і$ балансуючими потужностями. В статті обтрунтовано використання електричних станцій на базі відновлюваних джерел енергї, які оснащені системами акумулювання електроенергії на основі водню, в якості балансуючих потужностей оператора системи накопичення енергії. Зазначена система накопичення електричної енергї дозволяє перенесення енергї з періоду ї̈ «профіциту» в період ії «дефіuиту». Особливість водневої технології полягає в тому, що забезпечується найбільш економічний варіант зберігання електроенергії і подальще використання иісї запасеної енергії при тривалості розряду до кількох діб. Надано відомості про реальний пілотний проект впровадження накопичення енергї̈ з ВДЕ за водневою технологією, який впроваджується в Свропейському Союзі за програмою «Ногіzоп 2020». Гібридні станиї на ВДЕ, які оснащені водневими технологіями, можуть забезпечити балансування електроенергї в реальному часі. Технічно-досяжний потенціал ВДЕ в краӥні перевищує поточне річне споживання електроенергії України. Використання «зеленого» водню, виробленого без викидів в атмосферу СО2, сприяє вирімуванню екологічної проблеми з глобального потепління. Бібл. 9, табл. 1, рис. 3.
\end{abstract}

Ключові слова: глобальне потепління, Паризька угода, парникові гази, енергетична система, відновлювані джерела енергії, довготривале акумулювання електроенергії, стислий водень, балансування електроенергії.

\section{FEATURES OF THE INTRODUCTION OF ENVIRONMENTALLY FRIENDLY TECHNOLOGIES IN THE ENERGY SECTOR OF UKRAINE}

\author{
V. Khilko ${ }^{1}$, research officer, V. Ivanchuk ${ }^{1,2}$, student \\ ${ }^{1}$ Institute of Renewable Energy of the National Academy of Sciences of Ukraine, \\ 02094, 20A Hnata Khotkevycha St., Kyiv, Ukraine. \\ ${ }_{1,2}$ National Technical University of Ukraine «Igor Sikorsky Kyiv Polytechnic Institute», \\ 03056, 37 Peremohy Av., Kyiv, Ukraine.
}

The purpose of the article is to identify ways to reduce greenhouse gas emissions, which significantly contribute to the heat balance of the earth. The 2019 report on the gap in emission levels prepared by the United Nations Environment Program shows that measures on current policies to reduce harmful emissions are clearly inadequate. There is a constant growing interest in renewable energy in the world caused by environmental considerations: climate change and an increase in the content of greenhouse gases in the atmosphere. In Ukraine, the use of renewable energy sources, in particular wind and solar energy, is developing rapidly. At the same time, when introducing new capacities of renewable energy facilities, there are mains and system problems. Therefore, an increase in renewable energy capacities requires the creation of a more flexible energy system in Ukraine, including resolving the issue of reserve and balancing capacities. The article substantiates the use of power plants based on renewable energy sources, which are equipped with hydrogen-based electric energy storage systems, as balancing capacities of an energy storage system operator. The specified system of electric energy storage allows the transfer of energy from the period of its "surplus" to the period of its "deficit". The peculiarity of the hydrogen technology is that it provides the most economical option for storing electricity and the further use of this stored energy with a discharge duration of up to several days. Information is provided on a real pilot project for introducing energy storage from renewable energy sources using hydrogen technology, which is being implemented in the European Union under the "Horizon 2020" program. RES hybrid plants that are equipped with hydrogen technology can provide real-time energy balancing. The technically achievable potential of renewable energy in the country exceeds the current annual electricity consumption of Ukraine. The use of "green" hydrogen, produced without $\mathrm{CO}_{2}$ emissions, contributes to solving the environmental problem of global warming. Ref. 9, tabl. 1, fig. 3.

Keywords: global warming, Paris Agreement, greenhouse gases, energy system, renewable energy sources, long-term energy storage, compressed hydrogen, energy balancing.

(C) В.А. Хілько, В.Ю. Іванчук, 2020 


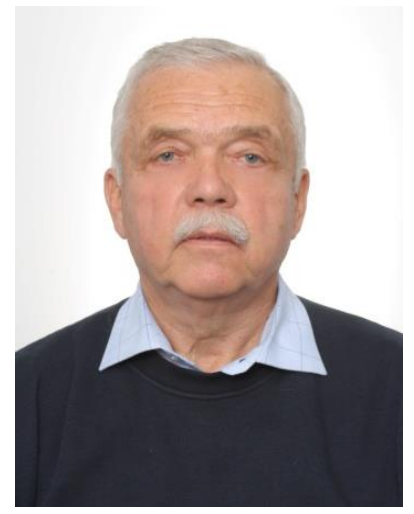

В.А. Хілько

V. Khilko

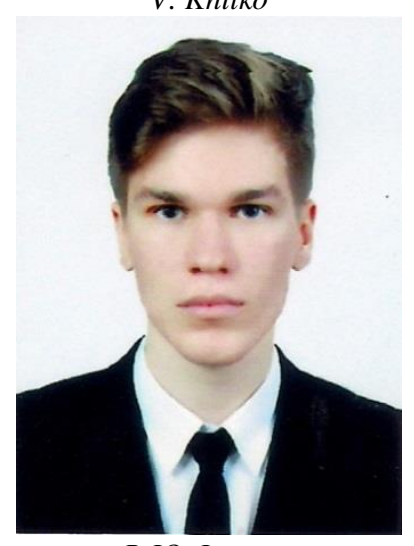

В.Ю. Іванчук

V. Ivanchuk
Відомості про автора: науковий співробітник Інституту відновлюваної енергетики НАН України.

Освіта: Київський технологічний інститут легкої промисловості, факультет електротехніки та автоматики.

Наукова сфера: відновлювана енергетика, економічний аналіз, електропостачання

Публікації: 37 публікації.

ORCID: 0000-0001-6348-2578

Контакти: +38 (050) 410-58-92

e-mail: vladimirkhilko@gmail.com

Відомості про автора: провідний інженер відділу №1 Комплексних енергосистем Інституту

відновлюваної енергетики НАН

України, студент Національного технічного університету України «Київський політехнічний інститут імені Ігоря Сікорського».

Освіта: студент 6-го курсу кафедри відновлюваних джерел енергії факультету електроенерготехніки та автоматики Національного технічного університету України «Київський політехнічний інститут імені Ігоря Сікорського».

Наукова сфера: відновлювана енергетика.

Публікації: 12.

ORCID: 0000-0002-0585-9610

Контакти: +38 (096) 533-03-86

e-mail: vladdos.iv98@ gmail.com
Author information: Research officer of the Institute of Renewable Energy of the NAS of Ukraine.

Education: Kyiv's Technological Institute of Light Industry on Electrical Engineering and Automatics Faculty. Research area: renewable energy, economic analysis, power supply. Publications: 37 publications.

ORCID: 0000-0001-6348-2578

Contacts: +38 (050) 410-58-92

e-mail: vladimirkhilko@gmail.com

Author information: Leading engineer of Department №1 of Complex Power Systems of the Institute of Renewable Energy of the NAS of Ukraine, student of the National Technical University of Ukraine "Igor Sikorsky Kyiv Polytechnic Institute".

Education: student of 6th course of the Department Renewable Energy Sources of Faculty of Electric Power Engineering and Automatics of the National

Technical University of Ukraine "Igor

Sikorsky Kyiv Polytechnic Institute".

Research area: renewable energy.

Publications: 12 .

ORCID: 0000-0002-0585-9610

Contacts: +38 (096) 533-03-86

e-mail: vladdos.iv98@gmail.com

\section{Перелік використаних позначень та скорочень:}

$\mathrm{OOH}$ - Організація Об'єднаних Націй;

ВДЕ - відновлювані джерела енергії;

$\mathrm{CO}_{2}$ - двоокис вуглецю;

НКРЕКП - Національна комісія, що здійснює державне регулювання у сферах енергетики та комунальних послуг;

Вступ. Генеральний секретар Організації Об'єднаних Націй (ООН) Антониу Гутерріш назвав глобальне потепління головною проблемою нашого часу [1]. Найбільш вірогідним наслідком глобального потепління $€$ викиди парникових газів в атмосферу. Джерелом надходження парникових газів на нашій планеті $\epsilon$ діяльність людини у сфері використання викопного палива та створенні глобальних пожеж. Підвищення температури може викликати цілу низку негативних явищ в локальних кліматичних умовах.

У національних планах і програмах країн світу провідна роль у зниженні рівня

\author{
ГАЕС - гідравлічна акумулюючи \\ електрична станція; \\ ККД - коефіцієнт корисної дії; \\ НАН - Національна академія наук.
}

антропогенних викидів парникових газів надається зниженню використання викопного палива й енергозбереженню, широкому впровадженню відновлюваних джерел енергії (ВДЕ).

На 21 рамковій конвенції ООН, яка відбулася у грудні 2015 р. в Парижі, було прийнято глобальну угоду з протидії зміні клімату на 2021 - 2030 pp. Україна ратифікувала зазначену угоду у 2016 році.

Паризька угода пропонує урядам усіх країн докладати максимальних зусиль щодо утримання приросту глобальної середньої температури до 2100 року «набагато нижче $2^{\circ} \mathrm{C}$ понад до 
індустріальних рівнів» і докладанні зусиль для обмеження зростання температури до рівня $1,5^{\circ} \mathrm{C}$.

Розрив в рівнях викидів. Доповідь 2019 року про розрив в рівнях викидів, підготовлений Програмою ООН 3 навколишнього середовища [2], свідчить, що заходи по поточній політиці скорочення викидів, явно недостатні (Див. Рис. 1). На рисунку надані зміни величин парникових газів, в еквіваленті двоокису вуглецю, до 2030 року. Видно, що за умови поточної політики, викиди парникових газів не зменшуються, а навіть суттєво збільшуються (блакитна лінія).

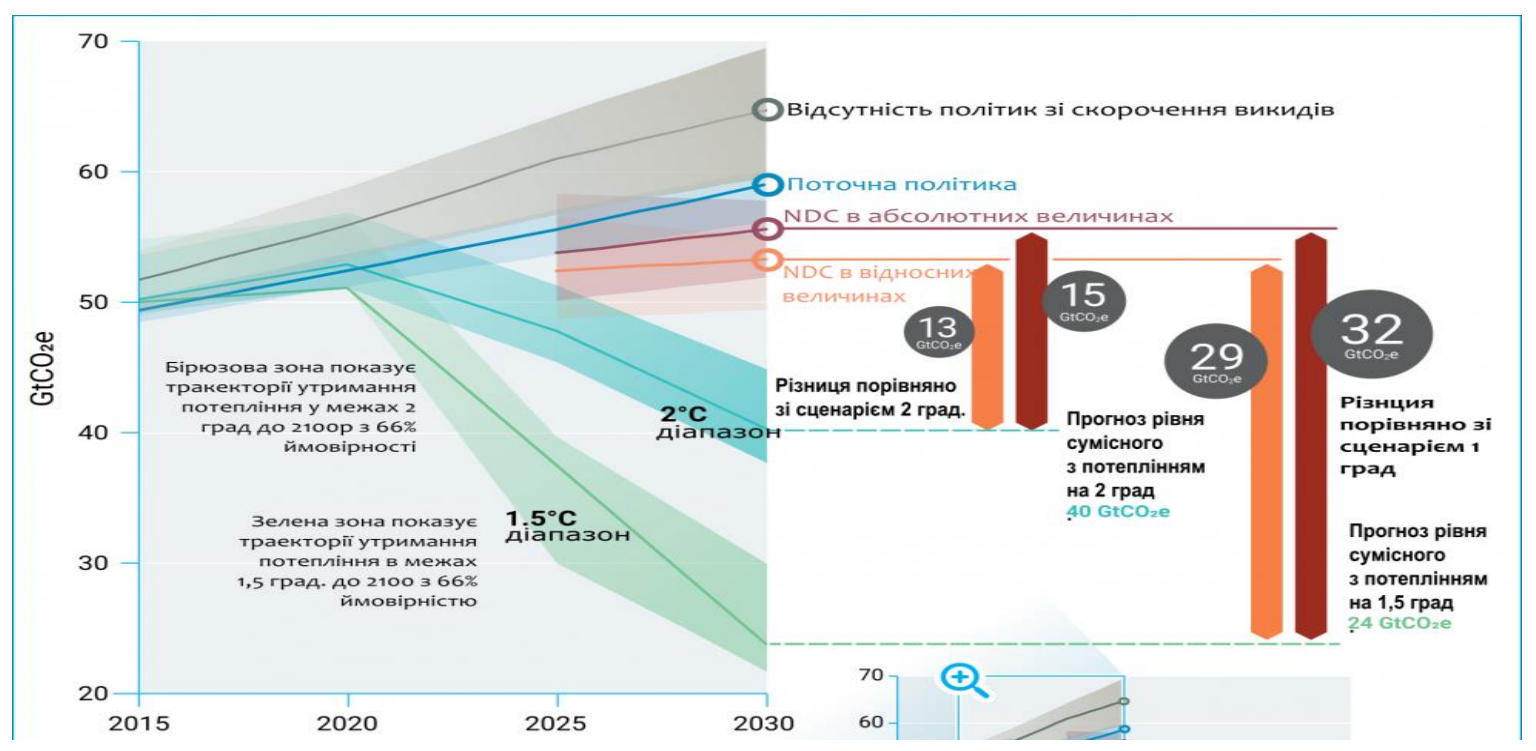

Джерело: Emissions Gap Report 2019, United Nations Environment Programme.

Рис. 1. Глобальні викиди парникових газів згідно з різними сценаріями і розрив в рівнях викидів до 2030 року: $N D C-$ національні вклади країн.

Fig. 1. Global greenhouse gas emissions according to various scenarios and gap in emission levels by 2030: NDC - national deposits of countries.

Різниця поточних показників із сценаріями $1,5^{\circ} \mathrm{C}-2,0^{\circ} \mathrm{C}$ свідчить, що початковий рівень амбіційності поставлених завдань необхідно підвищити в три - п'ять разів для досягнення цілей Паризької угоди. Згідно з оцінкою Міжурядової групи експертів зі зміни клімату, для обмеження глобального потепління знадобляться оперативні, масштабні і безпрецедентні зміни у всіх аспектах суспільства.

Однак навіть повномасштабна реалізація заходів щодо запобігання посиленню парникового ефекту не зможе повністю компенсувати шкоду, яка наноситься природі в результаті антропогенного впливу, забезпечивши лише мінімізацію наслідків.

В зв'язку 3 вище зазначеним, в світі спостерігається постійний зростаючий інтерес до відновлюваних джерел енергії, викликаний екологічними міркуваннями: зміна клімату i збільшення вмісту в атмосфері двоокису вуглецю $\left(\mathrm{CO}_{2}\right)$. Надається підтримка використання відновлювальних джерел енергії, 3 урахуванням зниження пов'язаних 3 цим витрат, 3 метою створення повністю безвуглецевої електро- енергетичної системи, а також запроваджується використання різних видів громадського транспорту з нульовим рівнем викидів.

Розвиток ВДЕ в Україні. В Україні швидко розвивається використання відновлюваних джерел енергії. За минулий 2019 рік було введено в дію 4505 МВт нових потужностей об'єктів на базі ВДЕ. А загальний обсяг потужностей на кінець року складає 6779 МВт [3]. У наступних роках, також планується вводити значні потужності ВДЕ. Разом $з$ тим, необхідно прийняти до уваги, що відновлювані джерела електричної енергії мають у часі тимчасовий або мінливий характер.

За вказаною обставиною в Україні існує проблема 3 інтеграцією ВДЕ в енергосистему. Певну частку виробленої ВДЕ електроенергії енергосистема може поглинати практично без будь-яких ускладнень, при перевищенні ж цієї величини виникають труднощі як мережевого, так i режимного характеру. Тому збільшення потужностей ВДЕ потребує вирішення питання 3 резервними i балансуючими потужностями. Змінний та неконтрольований характер вітряної та 
сонячної енергій може спричинити негативний вплив на стійкість негнучкої енергосистеми, що в свою чергу приводить до необхідності призупинення роботи станцій на ВДЕ.

Звіт ПрАТ «НЕК «Укренерго». Згідно звіту ПрАТ «НЕК «Укренерго» 3 оцінки відповідності (достатності) генеруючих потужностей, який затверджено НКРЕКП у березні 2020 року [4], визначено планування розвитку енергосистеми України.

На сьогодні у світі $€$ велика кількість технологій для вирішення задачі щодо створення гнучкої енергосистеми України, зокрема:
1. Високоманеврова газова генерація зі швидким стартом.

2. Високоманеврові ГАЕС.

3. Системи на базі систем акумулювання електричної енергії для підтримання та регулювання частоти.

4. Споживачі-регулятори на основі технологій акумулювання теплової енергії.

5. Системи які використовують енергії сонця і вітру для електролізних виробництв, i реалізують концепцію «Power to Gas».

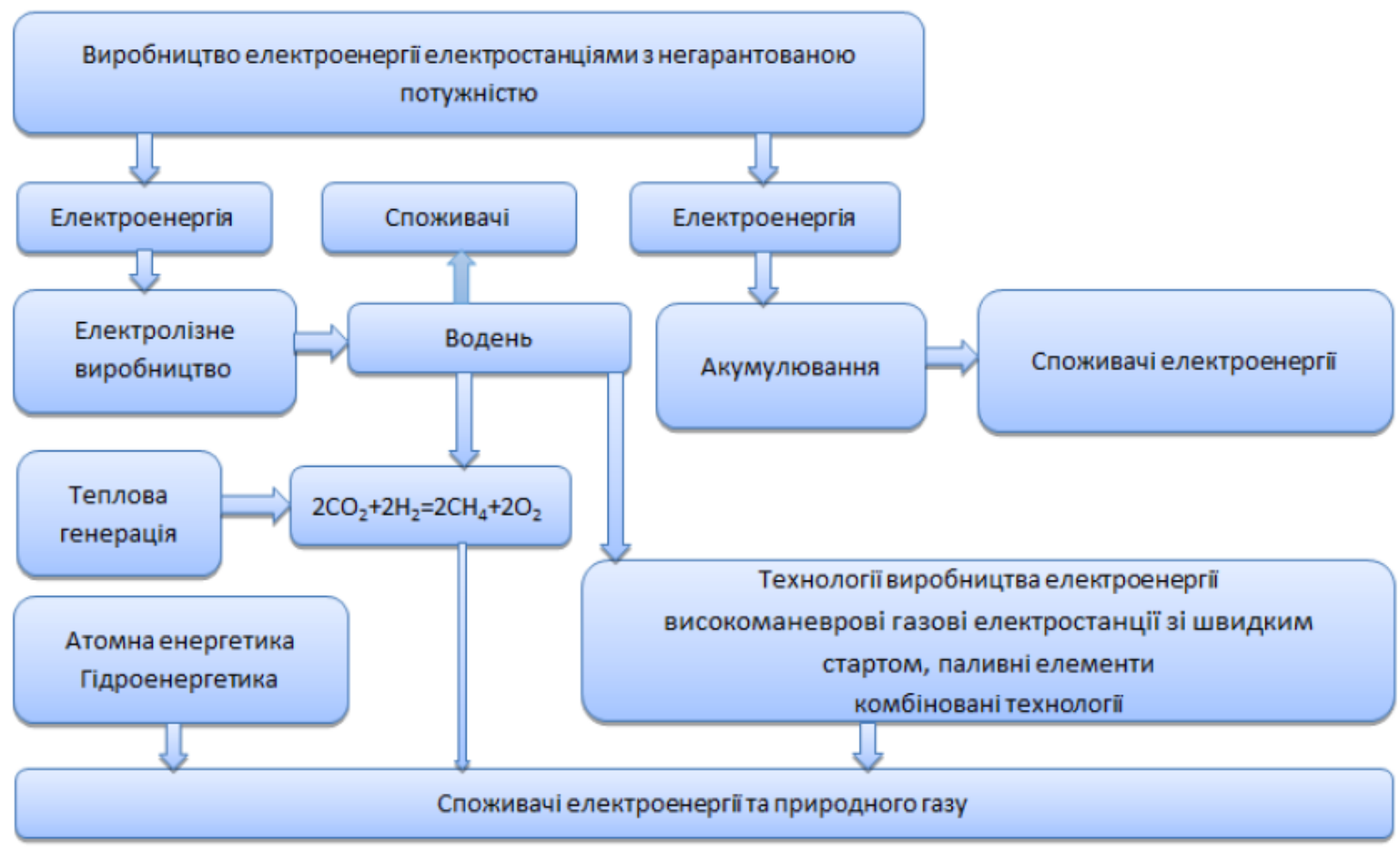

Джерело: ПрАТ «НЕК «Укренерго». Звіт з оиінки відповідності (достатності) генеруючих потужностей.

Рис. 2. Використання технологій «Power to Gas».

Fig. 2. Using of "Power to Gas" technologies.

Резервні джерела електроенергії на базі водню. 3 метою стабільного i безпечного функціонування енергосистеми знадобляться резервні джерела електроенергії. Причому такі, які можна активувати в більш-менш невеликі терміни, щоб швидко покрити дефіцит генерації через припинення роботи вітряних або сонячних електростанцій. Навпаки, стає актуальним також необхідність у швидких накопичувальних потужностях, які мають споживати «зайву» електричну енергію, вироблену ВДЕ. Ідеальним рішенням $€$ довготривале зберігання надлишкової електроенергії, одержуваної від вітряних i сонячних електростанцій, i подальше використання цієї запасеної енергії в разі потреби, тобто впровадження систем акумулювання електричної енергії для перенесення енергії 3 періоду iї «профіциту» в періоди іï «дефіциту».

Фахівці Міжнародного енергетичного агентства (IEA) вивчили техніко-економічні показники основних технологій накопичення електричної енергії [5]. Розглянемо співставлення показників п'яти технологій накопичення електричної енергії, яке надане в таблиці 1. 
Таблиця 1. Характеристики технологій довготривалого акумулювання електроенергії.

Table 1. Characteristics of long-term electricity storage technologies.

\begin{tabular}{|c|l|c|c|c|c|c|c|}
\hline \multirow{2}{*}{ № } & \multicolumn{1}{|c|}{ Параметр } & Од. вим. & $\begin{array}{c}\text { Насосне } \\
\text { накопичення } \\
\text { гідроенергії }\end{array}$ & $\begin{array}{c}\text { Енергія } \\
\text { стисненого } \\
\text { повітря }\end{array}$ & $\begin{array}{c}\text { Літій- } \\
\text { іонний } \\
\text { акумулятор }\end{array}$ & $\begin{array}{c}\text { Стислий } \\
\text { водень }\end{array}$ & $\begin{array}{c}\text { Енергія } \\
\text { аміаку }\end{array}$ \\
\hline 1 & $\begin{array}{l}\text { Вартість одноразових } \\
\text { капітальних витрат на } \\
\text { одиницю встановленої } \\
\text { потужності }\end{array}$ & дол./кВт & 1130 & 870 & 1820 & 2840 \\
\hline 2 & $\begin{array}{l}\text { Вартість одноразових } \\
\text { капітальних витрат на } \\
\text { одиницю виробленої } \\
\text { енергії }\end{array}$ & дол./кВт-г & 80 & 39 & 110 & 0,25 \\
\hline 3 & $\begin{array}{l}\text { Вартість поточних } \\
\text { операційних витрат на } \\
\text { одиницю встановленої } \\
\text { потужності }\end{array}$ & дол./кВт & 8 & 4 & 10 & 73 \\
\hline 4 & $\begin{array}{l}\text { Вартість поточних } \\
\text { операційних витрат на } \\
\text { одиницю виробленої } \\
\text { енергії }\end{array}$ & дол./кВт-г & 1 & 4 & 30 & 43 \\
\hline 5 & ККД перетворення & \% & 78 & 44 & 86 & 37 \\
\hline 6 & Тривалість експлуатації & років & 55 & 30 & 13 & 20 \\
\hline
\end{tabular}

Джерело: International Energy Agency. The Future of Hydrogen. June 2019 (Оригінал на англійській мові).

У сфері акумулювання електроенергії найбільш прийнятно використовувати водневу технологію, не зважаючи на невеликий ККД перетворення в обох напрямках, який складає $37 \%$.

Це пояснюється тим, що завдяки малим розмірам витрат на одиницю виробленої енергії, стислий водень і аміак стають більш привабливими (див. п.п. 2, 4). Серед різних технологій зберігання, розглянутих вище, стиснений водень $\epsilon$ найбільш економічним варіантом для тривалості розряду понад 2045 годин.

Таким чином технологія на основі водню найкраще підходить для акумулювання електроенергії в мегаватному масштабі від добового до сезонного періодів, що найбільш сприятливо для балансування енергосистеми.
Гібридні електричні станції. Вітряні та сонячні електростанції необхідно доповнити системами накопичення енергії за водневою технологією. Ці станції здійснюють накопичення енергії з ВДЕ у періоди наявності надлишкової енергії, та видачу в мережу електроенергії, коли електроенергія є дефіцитною. Алгоритм роботи зазначеного оператора системи накопичення енергії впроваджується подібно роботі гідравлічних акумулюючих електричних станцій. Станції на ВДЕ, які оснащені водневими технологіями, можуть забезпечити балансування електроенергії в реальному часі.

Приклад гібридної електричної станції на базі ВДЕ, яка оснащена системою накопичення/відпуску електроенергії за водневою технологією [6], надано на Рис. 3. 


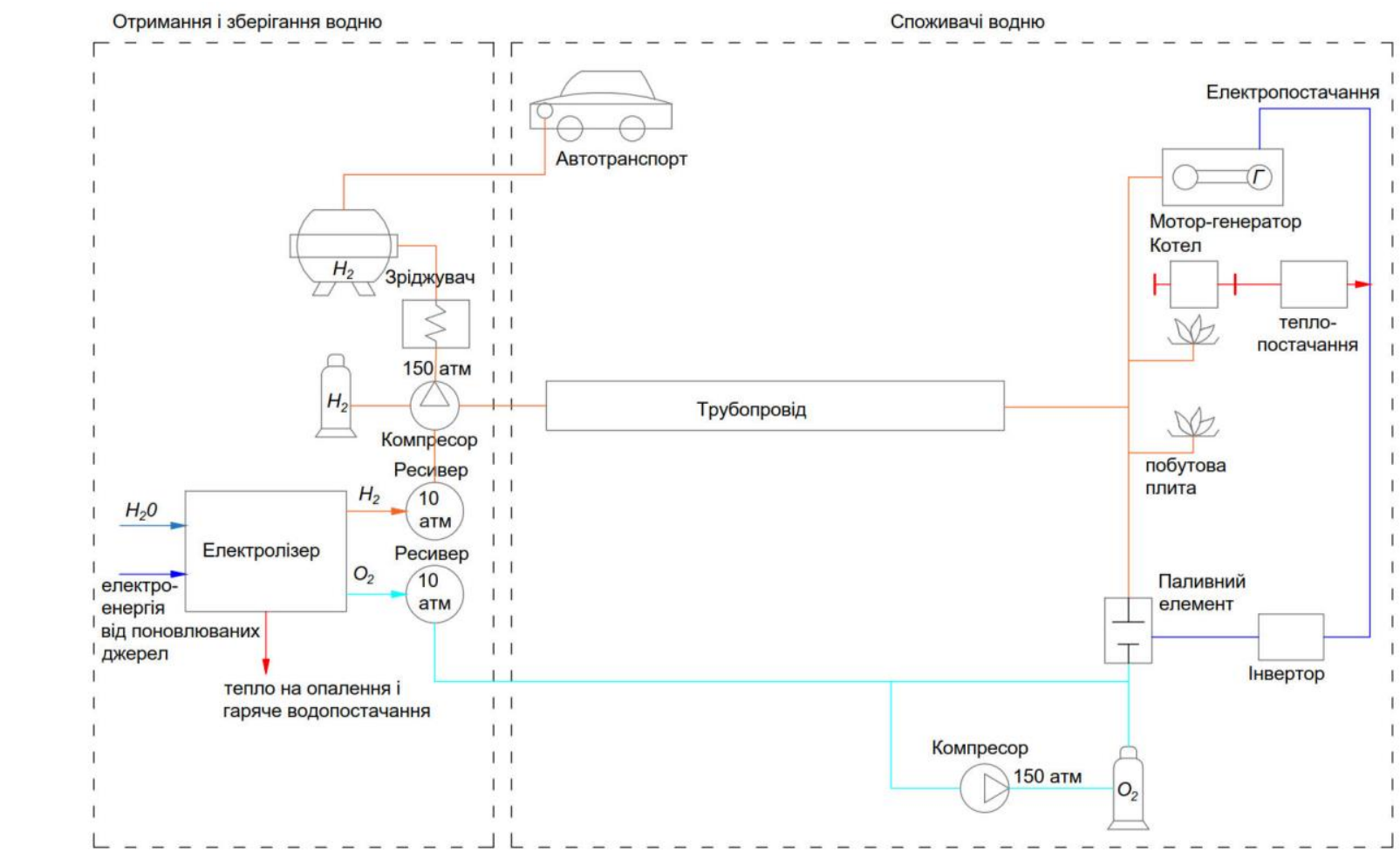

Джерело: IВЕ НАНУ

Рис. 3. Загальна схема комплексної гібридної енергетичної системи.

Fig. 3. General scheme of complex hybrid energy system.

Потрібно прийняти до уваги, що потреба перетворення запасеного водню в електроенергію не завжди існус. Запасений водень може бути безпосередньо використаний в якості палива для покриття таких потреб, як теплопостачання для промисловості і опалення приміщень.

Для цих комплексних станцій, на законодавчому рівні, повинні бути встановлені відповідні стимули для забезпечення балансування відпуску та реалізації електроенергії, та забезпечення безпеки енергетичної системи. 3 економічної точки зору використання водневої технології для споживання «зайвої» електроенергії $\epsilon$ позитивною обставиною, яка запобігає втратам електроенергії генерованої з ВДЕ у періоди мінімуму споживання.

Якщо в періоди мінімуму споживання країни використовувати для виробництва водню «зайву» електроенергію, яка виробляється в цей час 3 відновлюваних джерел, то виходить нешкідливе для клімату паливо у вигляді «зеленого» водню, вироблене без викидів в атмосферу $\mathrm{CO}_{2}$. Таким чином повністю вирішується екологічна проблема.

В травні 2020 року за підтримки Європейського Союзу, в рамках програми Horizon 2020 , розпочато реальний проект впровадження накопичення енергії 3 ВДЕ за водневою технологією [7]. Мета цього проекту полягає в виробництві водню 3 відновлюваної електроенергії, 3 подальшим використанням накопиченої енергії на комбінованих теплоелектростанціях.

Згідно «Концепції «зеленого» енергетичного переходу України до 2050 року»[8] основними напрямками декарбонізації економіки визначено: енергоефективність та енергозбереження; відновлювані джерела енергії; поводження з відходами; інноваційне сільське та лісове господарство. Теплові станції і та невелика кількість теплоцентралей, які зараз $є$ вугільними, мають бути замінені іншими.

В Україні у сфері використання водню $\epsilon$ широкий економічний інтерес. Впровадження в енергетиці такого відновлюваного джерела енергії, як «зелений» водень, виключає потребу в викопному паливі, найчастіше імпортованому. Великі програми у напрямку використання водневої технології розроблені у всіх передових країнах - Європейському Союзі, США, Канаді, Японії, Південній Кореї та ряді інших.

Технічно-досяжний потенціал ВДЕ в Україні. За дослідженнями Інституту відновлюваної енергетики НАН України [9], було визначено технічно-досяжний потенціал для 
створення на території України 874 ГВт потужностей на базі ВДЕ 3 середньорічним виробництвом електроенергії 2717 млрд. кВт год. Вказаний обсяг електричної енергії більше ніж в п’ятнадцять разів перевищує поточне річне споживання електроенергії в Україні і може забезпечити виробництво 505 млрд. н.м ${ }^{3}$ «зеленого» водню.

Таким чином можна перевести більшу частину енергетики України на водень універсальний і екологічно чистий енергоносій.

Висновки. Широке впровадження водневих технологій допоможе Україні виконати зобов'язання, взяті на себе в рамках Паризького угоди по клімату і суттєво припинить зміну клімату нашої планети, яка є спільною проблемою людства. Використання водню для акумулювання електроенергії збільшує рівень гнучкості енергосистеми при одночасному сприянні інтеграції відновлюваних джерел енергії. Станції на ВДЕ, які оснащені водневими технологіями, можуть забезпечити балансування електроенергії в реальному часі. Наша країна може стати прикладом здійснення як цілей по енергоефективності, так і цілей з відновлюваних джерел енергії, так як має великий потенціал в обох сферах.

Дана стаття підготовлена в рамках виконання проекту «Водень-2» цільових програм наукових досліджень НАН України «Розроблення наукових засад щодо впровадження технологій отримання водню з застосуванням відновлюваних джерел енергії та перспектив подальшого використання для енергетичних потреб в Україні», цільової програми наукових досліджень НАН України «Розвиток наукових засад отримання, зберігання та використання водню в системах автономного енергозабезпечення» країни (код виду науково-технічної діяльності за Державним класифікатором України: I.2 13.14.08).

1. UN chief appeals to G7 leaders for strong commitment and political will to tackle climate emergency. [Електронний ресурс]. URL: https://news.un.org/en/stor y/2019/08/1044921. (дата звернення: 27.05.2020).

2. The Emissions Gap Report 2019. United Nations Environment Programme. [Електронний ресурс]. URL: https://www.unenvironment.org/resources/emissions-gapreport-2019. (дата звернення: 27.05.2020).

3. Інформація щодо потужності та обсягів виробництва електроенергії об'єктами відновлюваної електроенергетики, яким встановлено «зелений» тариф (станом на кінець IV кварталу 2019 року). Державне агентство 3 енергоефективності та енергозбереження України. 2020. 4 с. [Електронний ресурс]. URL: https://saee.gov.ua/uk/content/informatsiyni-materialy (дата звернення: 27.05.2020).

4. Затверджено Звіт 3 оцінки відповідності (достатності) генеруючих потужностей - 2019. Національна комісія, що здійснює державне регулювання у сферах енергетики та комунальних послуг. 2020. [Електронний ресурс]. URL: http://www.nerc.gov.ua/index last.php?news=10017 (дата звернення: 27.05.2020).

5. IEA G20 Hydrogen report: Assumptions. [Електронний ресурc]. URL: https://www.iea.org/reports /the-future-of-hydrogen/data-and-assumptions

(дата звернення: 27.05.2020).

6. Будько М.О. Використання зеленого водню для отримання альтернативних енергоносіїв. Матеріали XXI конференції «Відновлювана енергетика та енергоефективність у 21 столітті». 2020. С. 199-202. [Електронний ресурc]. URL: https://www.ive.org.ua/?pa ge_id=2397 (дата звернення: 27.08.2020).

7. The worlds first integrated power-to-X-to-power hydrogen gas turbine demonstrator. [Електронний pecypc]. URL: https://press.siemens.com/global/en/pressr elease/hyflexpower-worlds-first-integrated-power-xpower-hydrogen-gas-turbine-demonstrator (дата звернення: 27.05.2020).

8. Концепція «зеленого» енергетичного переходу України до 2050 року. Міністерство енергетики та захисту довкілля України. 2020. [Електронний ресурс]. URL: https://menr.gov.ua/news/34424.html (дата звернення: 27.05.2020).

9. Кудря С.О. Електроенергетичний потенціал відновлюваних джерел енергії України. Матеріали XXI конференції «Відновлювана енергетика та енергоефективність у 21 столітті». 2020. С. 26-33. [Електронний ресуpc]. URL: https://www.ive.org.ua/?pa ge id=2397 (дата звернення: 27.08.2020).

\section{REFERENCES}

1. UN chief appeals to G7 leaders for strong commitment and political will to tackle climate emergency. [Electronic resource]. URL: https://news.un.org/en/story/2 019/08/1044921 (Applying date: 27.05.2020). [in English].

2. The Emissions Gap Report 2019. United Nations Environment Programme. [Electronic resource]. URL: https://www.unenvironment.org/resources/emissions-gapreport-2019 (Applying date: 27.05.2020). [in English].

3. Informaciya shhodo potuzhnosti ta obsyagiv vyrobnycztva elektroenergiyi obyektamy vidnovlyuvanoyi elektroenergetyky, yakym vstanovleno «zelenyj» taryf (stanom na kinecz IV kvartalu 2019 roku). [Information on the capacity and volume of electricity production by renewable electricity facilities, which have a "green" tariff (as of the end of the fourth quarter of 2019)]. The state agency on energy efficiency and energy saving of Ukraine. 2020. 4 p. [Electronic resource]. URL: https://saee.gov.ua/ 
uk/content/informatsiyni-materialy (Applying date: 27.05.2020). [in Ukrainian].

4. Zatverdzheno Zvit $\mathrm{z}$ ocinky vidpovidnosti (dostatnosti) generuyuchyx potuzhnostej-2019. [Approved Report on conformity assessment (sufficiency) of generating capacities - 2019]. National commission for state regulation in the fields of energy and communal services. 2020. [Electronic resource]. URL: http://www.ne $\underline{\text { rc.gov.ua/index last.php?news }=10017 \text { (Applying date: }}$ 27.05.2020). [in Ukrainian].

5. IEA G20 Hydrogen report: Assumptions. [Electronic resource]. URL: https://www.iea.org/reports/th e-future-of-hydrogen/data-and-assumptions (Applying date: 27.05.2020). [in English].

6. Budko M.O. Vykorystannya zelenogo vodnyu dlya otrymannya alternatyvnyx energonosiyiv. [Using of green hydrogen to obtain alternative fuels]. Proceedings of the XXI conference "Renewable energy and energy efficiency in the 21st century“. 2020. Pp. 199-202. [Electronic resource]. URL: https://www.ive.org.ua/?page_id=2397 (Applying date: 27.08.2020). [in Ukrainian].
7. The world's first integrated power-to-X-to-power hydrogen gas turbine demonstrator. [Electronic resource]. URL: https://press.siemens.com/global/en/pressrelease/hyf lexpower-worlds-first-integrated-power-X-powerhydrogen-gas-turbine-demonstrator (Applying date: 27.05.2020). [in English].

8. Koncepciya «zelenogo» energetychnogo perexodu Ukrayiny do 2050 roku. [The conception of "green" energy transition of Ukraine until 2050]. Ministry of energy and environmental protection of Ukraine. [Electronic resource]. URL: https://menr.gov.ua/news/34424.html (Applying date: 27.05.2020). [in Ukrainian].

9. Kudrya S.O. Elektroenergetychnyj potencial vidnovlyuvanyx dzherel energiyi Ukrayiny. [Electric power potential of renewable energy sources in Ukraine]. Proceedings of the XXI conference "Renewable energy and energy efficiency in the 21 st century". 2020. Pp. 26-33. [Electronic resource]. URL: https://www.ive.org.ua/?page _id=2397 (Applying date: 27.08.2020). [in Ukrainian].

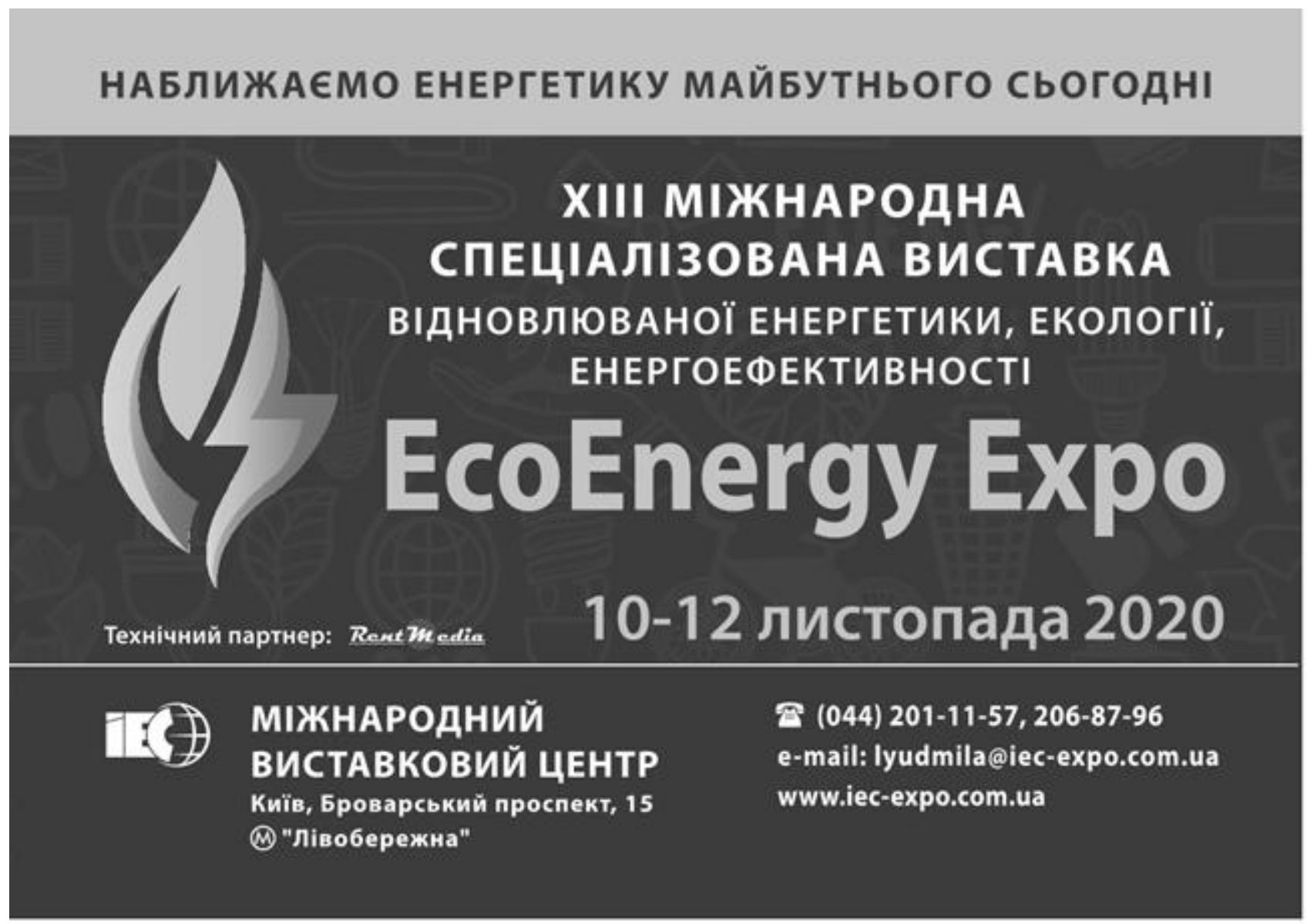

